\title{
CTTRANSIT Operates New England's First Fuel Cell Hybrid Bus
}

C:

onnecticut Transit (CTTRANSIT), owned by the

Connecticut Department of Transportation, provides fixed

route transportation services to three major metropolitan areas in the state: Hartford, New Haven, and Stamford.

CTTRANSIT is committed to improving the environment for its passengers and the communities it serves. For the past several years, it has been investigating new technologies and fuels for its fleet that are more efficient and produce fewer emissions. These include using ultra-low-sulfur diesel fuel blended with biodiesel in the current fleet, retrofitting existing buses with diesel particulate filters, purchasing hybrid electric buses, and more recently, demonstrating a prototype fuel cell bus. Fuel cell buses powered by hydrogen produce no tailpipe emissions and can help reduce U.S. dependence on imported oil.

In April 2007, CTTRANSIT unveiled its hybrid fuel cell busa first for the New England region. The fuel cell bus operates on the Star Shuttle route in Hartford. Hartford is the largest of the three areas. CTTRANSIT services and operates over 30 local and 23 express routes in and around the capital area. The Star Shuttle route offers free service around the downtown area, connecting hotels with the convention center and many other landmarks.

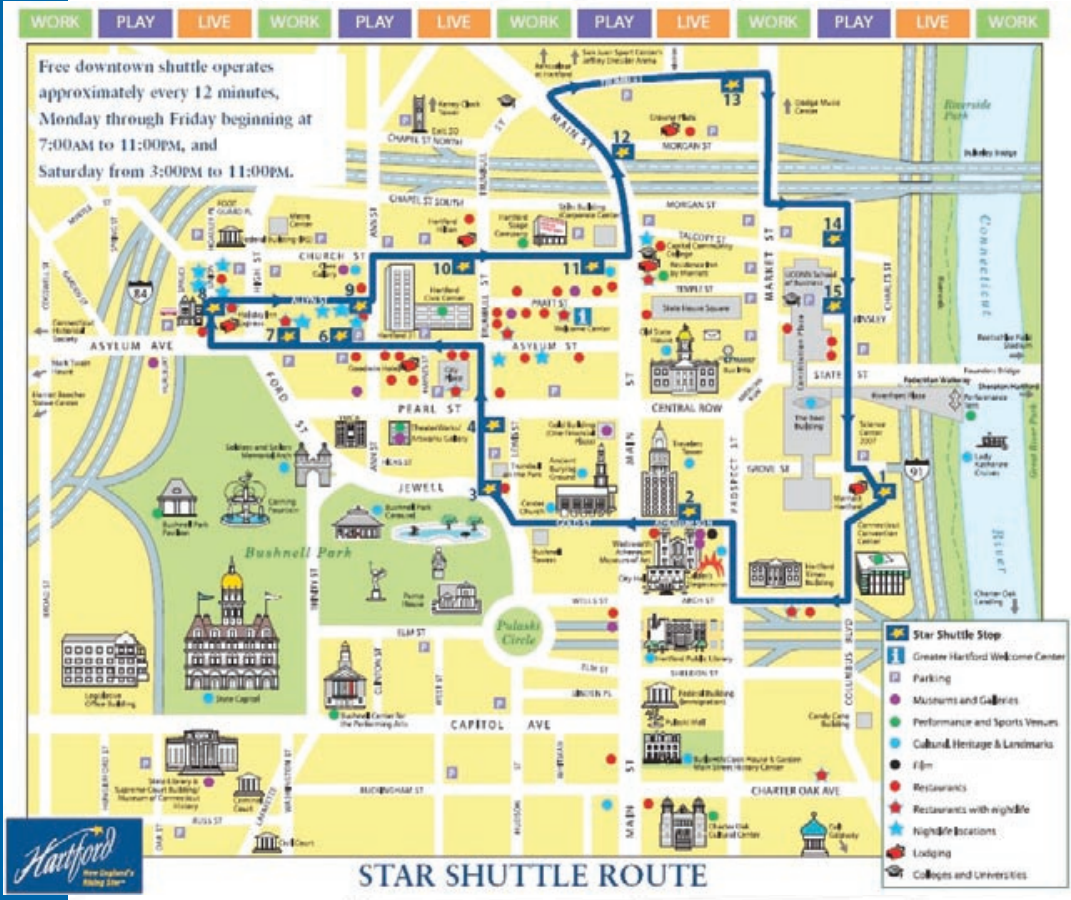

Map of the Star Shuttle's routes and stops

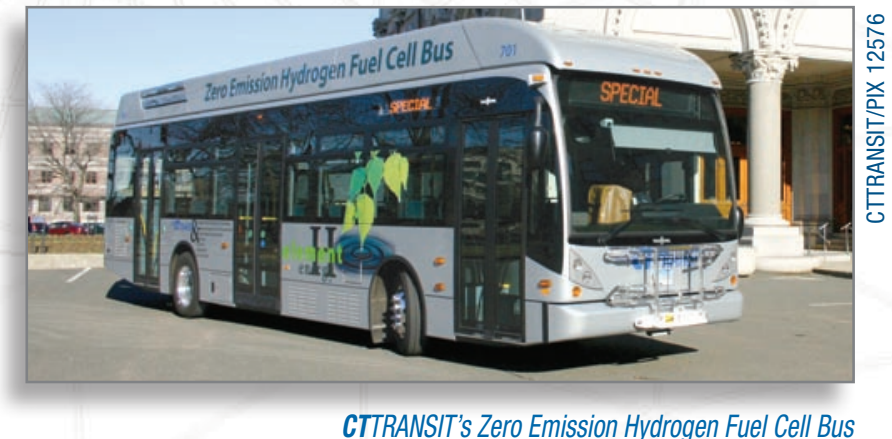

The U.S. Department of Transportation's Federal Transit Administration (FTA) and the U.S. Department of Energy (DOE) are collaborating to develop, demonstrate, and evaluate fuel cell technology in transit applications. FTA is focused on fuel cell buses, while DOE is focused on light-duty fuel cell vehicles and hydrogen fueling infrastructure. DOE validates fuel cell technology in a variety of applications, including transit, with the overall goal of determining the current status of the technology and assessing the progress toward technology readiness.

CTTRANSIT also plans to operate the bus on other routes to test the performance in a variety of transit service conditions, such as steep grades and high speeds.

The prototype fuel cell bus was developed as a collaborative effort by UTC Power, ISE Corporation, and Van Hool. The bus uses a fuel cell power system manufactured by UTC Power in a hybrid electric drive system designed by ISE. It was part of an earlier procurement of four fuel cell buses currently in operation at AC Transit and SunLine in California. Testing the bus in Connecticut will assist the project partners in understanding how the system operates in a cold, humid climate.

THE HYBRID SYSTEM is a series configuration, meaning the powerplant is not mechanically coupled to the drive axle. The powerplant and energy storage system work together to provide electricity to two electric drive motors that are coupled to the driveline through a combining gearbox.

When the bus needs extra power, both the powerplant and energy storage system provide power to the drive motors. When the power requirements of the bus are low, the powerplant recharges the energy storage system. The hybrid system is also capable of regenerative braking, which captures the energy typically 
expended during braking and uses it to recharge the energy storage system. Each component of the propulsion system is carefully controlled through an ISE-developed operating system.

The primary power source for the hybrid system is UTC Power's PureMotion* $120 \mathrm{~kW}$ proton exchange membrane (PEM) fuel cell system. These fuel cells operate at near-ambient pressure, which eliminates the need for a compressor and results in a more efficient system and quieter operation. The energy storage for the system consists of three ZEBRA (sodium nickel chloride) batteries.

The fuel cell bus fills up at a hydrogen fueling station at UTC Power's headquarters, located only a few miles from the CTTRANSIT facility. The hydrogen supplied to the station is a byproduct of brine production from Niagara Falls hydropower. The hydrogen collected is transported by pipeline to the supplier where it is purified, compressed, and liquefied for transportation to the fueling station.

CTTRANSIT is currently collaborating with the U.S. Department of Energy's (DOE) Hydrogen, Fuel Cells \& Infrastructure Technologies Program to evaluate the fuel cell bus. The agency will run the bus in revenue service for a minimum of two years. During this time, DOE's National Renewable Energy Laboratory

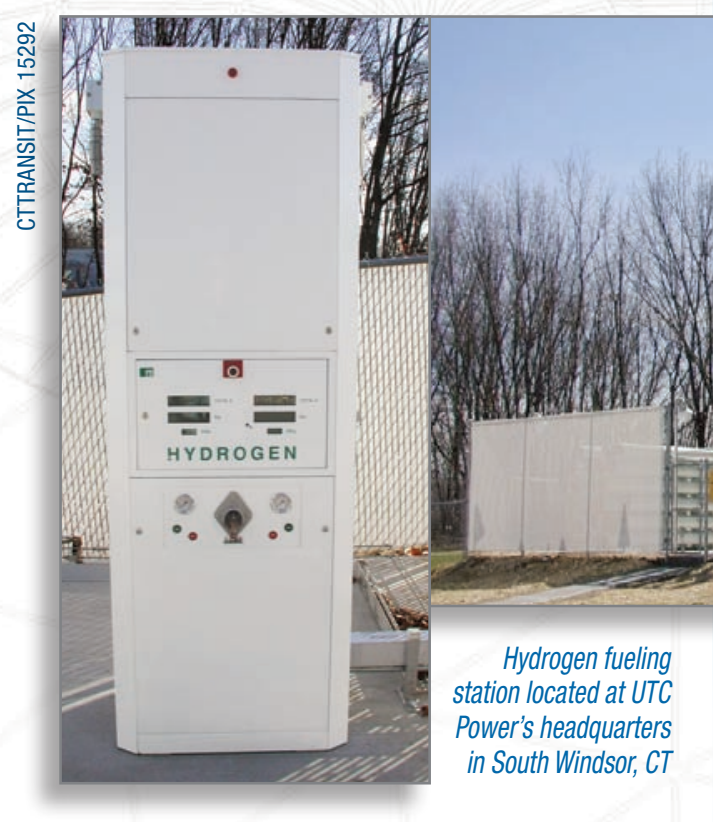

(NREL) will collect and analyze performance and operations data. The evaluation of the buses at CTTRANSIT is one of several DOE projects that support the research and development of highly efficient, low- or zero-emission fuel cell power systems. The results are important in understanding the state of the technology and the work that still needs to be done. Information gathered during the demonstration will help researchers assess the status of the technology and aid fleets in making informed purchase decisions. Results will be used to guide future research and development.

\section{CTTRANSIT Fuel Cell Facts}

\begin{tabular}{|l|l|}
\hline Bus Chassis & Van Hool, A330 low-floor \\
\hline Model Year & 2006 \\
\hline Length/Width/Height & $40 \mathrm{ft} / 102 \mathrm{in} / 137$ in \\
\hline GVWR & $43,420 \mathrm{lb}$ \\
\hline Seats & 30 seated (or 26 seated with 2 wheelchairs) and 20 standees \\
\hline Wheel Base & 228 in \\
\hline Service & Star Shuttle downtown service initially, then all routes \\
\hline Drive System & Siemens ELFA series hybrid system \\
\hline Powerplant & UTC Power PureMotion* 120, PEM fuel cell power system; two stacks, 120 kW total \\
\hline Propulsion Motor & Two AC induction motors, 170 kW total \\
\hline Energy Storage & ZEBRA (sodium nickel chloride), three modules, $95 \mathrm{~kW}$ total \\
\hline Accessories & Electrically driven \\
\hline Fuel & Gaseous hydrogen at 5,000 psi \\
\hline Hydrogen Storage & $\begin{array}{l}\text { Eight on-board, carbon fiber-wrapped tanks by Structural Composites Industries, } \\
\text { approximately } 50 \text { kg total storage }\end{array}$ \\
\hline Emissions Equipment & Zero emissions \\
\hline
\end{tabular}

\footnotetext{
* PureMotion is a registered trademark of UTC Power
}

Increase Your H2IQ!

Visit: www.hydrogen.energy.gov

Produced by the National Renewable Energy Laboratory (NREL)

NREL is a U.S. Department of Energy National Laboratory operated by Midwest Research Institute • Battelle

DOE/G012008-2529

February 2008

Printed with a renewable-source ink on paper containing at least $50 \%$ wastepaper, including $10 \%$ postconsumer waste. 